\title{
In the middle of nowhere: Gated neighbourhoods in Vilnius region as a new lifestyle?
}

\author{
Dovilè KRUPICKAITE் $\dot{1}^{1}$, GinTARĖ POCIŪTÉ ${ }^{2}$ and LAURA PECIUKONYTÉ ${ }^{3}$
}

\begin{abstract}
This article provides an overview about the new tendencies on the Lithuanian housing market shedding light on the development of the gated and guarded neighbourhoods (GGNs). Field surveys and interviews with developers, residents as well as local planning authorities in Vilnius and its surroundings provide the basis of discussion about the "fencing phenomenon". Can this phenomenon be explained by such factors like socio-economic segregation in the city, extensive marketing or a specific niche on the market? The research results show that gated neighbourhoods are established not only because of the need to prevent residents from violence or to show their social status but also to protect their lives from the chaotic and socially unstable outside world where the gates have more symbolic meanings.
\end{abstract}

Keywords: gated communities, gated and guarded neighbourhoods, residential segregation, post-socialist cities, Vilnius, Lithuania

\section{Introduction}

Gated and guarded neighbourhoods (GGNs) have been increasingly spreading in most European countries, including those where this form of housing had been rare until the 1990s (i.e. post-socialist countries). Researchers started to explore the underlying factors and formulated theories about the emergence of GGNs (GLasze, G. 2003, 2005; Lentz, S. and Lindner, P. 2003; Madore, F. and Glasze, G. 2003; Raposo, R. 2003, 2006; Wehrhahn, R. 2003; Blandy, S. 2006; Blinnikov, M. et al. 2006; Lentz, S. 2006; Stoyanov, P. and Frantz, K. 2006; Wehrhahn, R. and Raposo, R. 2006; Schmigiel, C. 2009).

${ }^{1}$ Vilnius University, Faculty of Natural Sciences, M. K. Čiurlionio 21/27, LT-03101 Vilnius, Lithuania. E-mail: dovile.krupickaite@gf.vu.lt

${ }^{2}$ Lithuanian Research Centre, Institute of Human Geography and Demography, A. Goštauto

11, LT-01108 Vilnius, Lithuania. E-mail: gintarei.pociutei@gmail.com

${ }^{3}$ Vilnius University, IIRPS, Vokiečių 10, LT-01130 Vilnius, Lithuania.

E-mail: laura.peciukonyte@tspmi.vu.lt 
The prevalence and popularity of GGNs is explained by various factors. Firstly, according to the club goods theory, the collective management and use of common resources is more cost-effective (Glasze, G. 2005). Consequently, strive for efficiency encourages the prevalence and popularity of GGN. The popularity of GGNs is also explained by the effect of certain global processes, such as ongoing socio-economic restructuring, democracy and government crises, and the withdrawal of state (Glasze, G. 2005; Lee, S. and Webster, C. 2006). Finally, historical, socio-economic and regional factors might also play a role in the emergence of GGNs (GLAsze, G. 2005).

Despite the extensive previous research on gated neighbourhoods, there is a lack of comprehensive understanding about this phenomenon. For instance, there is a need to analyse the potential influence of westernisation on the forms and functions of these neighbourhoods. Also, there is a paucity of studies examining the quality of life in GGNs. Finally, there is a lack of research analysing factors contributing to the emergence of GGNs in various post-socialist countries. Taken all these into account, the main objective of this article is to contribute to the literature by exploring the reasons of GGNs appearance in one particular post-socialist country - Lithuania.

The appearance of GGNs in Lithuania, compared to other post-socialist countries (for example the Czech Republic, Hungary, Poland, or Russia) was late. The first GGN appeared at the beginning of the 21th century and became popular in the middle of the first decade. This period coincided with the country's robust economic growth and a real-estate boom.

Earlier papers in the field analysed the development of GGNs and concentrated mainly on morphological aspects (PocıūTĖ, G. 2007; Pocı̄ūTĖ, G. and Krupickaitė, D. 2007; Krupickaitė, D. and Pociūtė, G. 2009). These initial studies revealed that the structure of Lithuanian GGNs differs from typical GGN models. The latest research on Lithuanian GGNs concentrated on exploring why residents choose to move in such estates. It was found that the key reasons influencing the choice of Lithuanian residents to live in GGNs differ from other countries (e.g. USA, Russia, Latin America) where security and exclusivity are the key reasons why people choose to live in GGNs, while in Lithuania the main motivation is to live close to nature and to be surrounded by people with similar status.

This article is structured as follows: firstly, factors causing the emergence of GGNs in various countries are overviewed. Secondly, the methodology of the research is presented. Then the morphological characteristics of GGNs in the Vilnius region are introduced. Fourthly, the role of key stakeholders, e.g. investors, residents and local government representatives, regarding the development of GGNs in Lithuania, are analysed. Finally, in the conclusions, the unique characteristics of GGN development in Lithuania are discussed, with reference to the tendencies of other countries. 


\section{Between West and East: similarities and differences in the development of GGNs worldwide}

The emergence of GGNs is mostly explained by such factors as safety, social homogeneity, prestige, and privacy. However, the role of these factors can be very different in various parts of the world. In Western Europe GGNs can be found in Spain (Wehrhahn, R. 2003), Portugal (Raposo, R. 2003; Wehrhahn, R. and Raposo, R. 2006), France (Madore, F. and Glasze, G. 2003), the United Kingdom (Blandy, S. and Parsons, D. 2003; Blandy, S. 2006). However, the gating phenomenon is not widespread in these countries, and the number of people living in such enclaves is relatively low. Typically, the residents of GGNs in Western and Southern European countries are middle- and upper-middle class citizens, who wish to have more privacy and pursue more quality life.

As opposed to Western Europe GGNs are very popular and widespread in the USA. They differ by type, lifestyle orientation, the functionality they provide, and the purpose for which they are built (BLANKLEY, E.J. and SNYDER, M.G. 1997; Low, S. 2004). Social scientists usually treat the American GGN as a prototype for other similar compounds all around the world, and explain the emergence of gated neighbourhoods in other countries by the growing influence of American culture (especially in Eastern European countries). Many scholars noted that the fear from rising crime rates and peoples' need to "feel safe" is one of the key drivers why US residents tend to move to GGNs in large numbers (e.g. Blankley, E.J. and SNyder, M.G. 1997; Marcuse, P. 1997; McKenzie, E. 1998; Gmünder, M. et al. 2000; Handley, J. 2002; Low, S. 2004; FrANTZ, K. 2001, 2006). GLAssner, B. (1999) even stated that gated neighbourhoods are a physical declaration of the "culture of fear".

Again, in Russia GGNs play a different role. Rather than serving as instruments of security they typically serve as "ghettos" for the rich. The GGN phenomenon is not new in Russia. During the Soviet Union gated and strictly guarded settlements were built for the leaders in order to "separate them from the controlled masses" (Voslensky, M.S. 1984; Blinnikov, M. et al. 2006). After the collapse of the Soviet Union, GGNs became popular among the new rich. Scholars observed that these enclaves created a new "capitalist landscape" (Brady, R. 1999; Blinnikov, M. et al. 2006).

GGNs in Russia are highly protected settlements available only for the top elite, i.e. those who can afford paying the price (RUdolPH, R. and Lentz, S. 1999; Lentz, S. and Lindner, P. 2003; Lentz, S. 2006). They are mostly located around Moscow or Sankt Petersburg (BLInnikov, M. et al. 2006) are very exclusive and without comparable examples from other countries. Prestige, a desire of wealthy people to separate themselves from the masses by high fences, and a desire to live in beautiful green spaces on the outskirts of Russia's largest cities remain the key driving factors for the emergence of GGNs in Russia (BLINNIKov, 
M. et al. 2006). Life in GGNs allows for the wealthy people to feel safer, not be disconnected from the city, but at the same time be "secluded away from the underprivileged and frequently landless masses" (Blinnikov, M. et al. 2006).

In East Central Europe a gradual spread of GGNs has been reported in the last decade (Stoyanov, P. and Frantz, K. 2006; Frantz, K. 2006; CsÉfalvay, Z. 2009, 2012; Csizmady, A. and Csanádi, G. 2009; Hegedús, G. 2009a,b; Johnson, C. 2009; Kovács, Z. and Hegedús, G. 2014; Pociūtė, G. and Krupickaitė, D. 2007; PolansKa, D.V. 2010a, 2010b). The first studies exploring the causes of the emergence of GGNs emphasised that this process was and is highly influenced by American culture. After the collapse of communism American type GGNs were considered as desirable form of housing, and they were constructed as a novel form of settlement in post-socialist countries. In other words, the desire to "fulfil an American dream" (STANILOv, K. 2007) or to live as contemporary Americans were key driving factors for the emergence of the first GGNs in East Central Europe. However, latest research indicates that it is no longer the case.

Recent research has revealed that there is no single overriding explanation for the emergence of such enclaves in ECE (Cséfalvay, Z. and Webster, C. 2012). A numerous studies found that privacy and prestige are important factors influencing their appearance and many residents move to GGNs for seeking social homogeneity (Lentz, S. and Lindner, P. 2003; Storanov, P. and Frantz, K. 2006; Schmigiel, C. 2009; Hegedús, G. 2009b, Polanska, D.V. 2010a, b). Other scholars, however, emphasise that GGNs necessarily increase the level of social segregation within these societies (BRADE, I. et al. 2009; SCHMIGIEL, C. 2009; Polanska, D.V. 2010b). Bitusikova, A. and Luther, D. (2010) refer to the GNNs in ECE as "ghettos of homogeneity". Aesthetics and environmental aspects are also noted as factors contributing to the popularity of GGNs (Stoyanov, P. and Frantz, K. 2006; Cséfalvay, Z. 2009, Polanska, D.V. 2010a).

Researchers note that the environmental characteristics, such as "fresh air, water, silence" (Negura, O. 2009); "green surroundings and closeness to nature" (PolansKa, D.V. 2010a) are typically emphasized in advertisements of GGNs in post-socialist countries instead of focussing on the security factor. Even though the importance of security as a rationale for moving to GGNs in ECE countries is acknowledged by many authors (Pociūtė, G. and KRUPICKAItė, D. 2007; Schmigiel, C. 2009; Hegedús, G. 2009b; Cséfalvay, Z. and Webster, C. 2012), nevertheless, it is not regarded as crucial as in the USA or Russia.

\section{Research methodology}

In order to find out the increasing popularity of GGNs in Lithuania both qualitative and quantitative methods, including content analysis, semi-structured in-depth interviews with various target groups, field survey were applied. 
The results presented in this article are based on the material collected during 2010. As GGN does not have special statistical definition in Lithuania, i.e. they are counted as detached houses or block of flats, there is no official statistics about their occurrence. Therefore, before exploring the reasons why GGNs have become so popular in the country, the spatial distribution of GGNs, their locations, size and morphological characteristics had to be clarified. Although there was some data on the distribution and morphology of GGNs collected during the field study in 2007, the information for this article had to be updated. Consequently, a new field survey was carried out in July 2010.

During the survey the whole territory of Vilnius city municipality was investigated and all new housing compounds (3 or more complex of houses) that were built after the year 2000 were recorded. Also, the morphological characteristics of those settlements (e.g. plot size, number of buildings, forms of security etc.) were registered. Houses with the following characteristics were assigned to GGN: 1) the land where they stand is fully fenced and entrance to it is limited for cars and pedestrians); 2) the territory is under video surveillance or protected by security staff.

Secondly, "Neries kilpos" gated neighbourhood was chosen for the purpose of case study, because its characteristics (size, security installations, socio-economic status) are very typical for other Lithuanian GGNs. "Neries kilpos" neighbourhood is located $35 \mathrm{~km}$ from Vilnius centre. It was built on a 10 ha land between 2005 and 2007. The neighbourhood consists of 33 houses on 40 plots. All basic infrastructure necessary for such type of settlement are provided (i.e. roads, water well, sewage systems, water treatment equipment, natural gas reservoir, and internet connection).

In addition, there are children's playground, basketball, tennis and volleyball courts, and a house for community purposes. "Neries kilpos" is well secured by fences (Photo 1), automatic gates and video cameras. Finally, the whole territory is supervised by the territory manager on workdays. The residents of the settlement have established the owners' community in 2007. This community actively deals with common problems and fosters community development (sport competitions, spring "cleaning bee", school start event etc.). The socio-demographic structure of "Neries kilpos" is quite homogeneous. The majority of the residents belong to the upper-middle class (monthly income per family is above 2000 euro), most of them have a university degree, are employed or free-standing high quality specialists, businessmen, medical doctors etc. Finally, the family structure is also typical, in most cases families consist of two adults and two children.

In-depth interviews were carried out to find out the main driving forces behind the mushrooming of GGNs in Vilnius and its surroundings. Interviews were made with residents and developers of the GGN, as well as with local government officials responsible for urban development. The research team conducted 21 interviews in total. Five were made with residents 


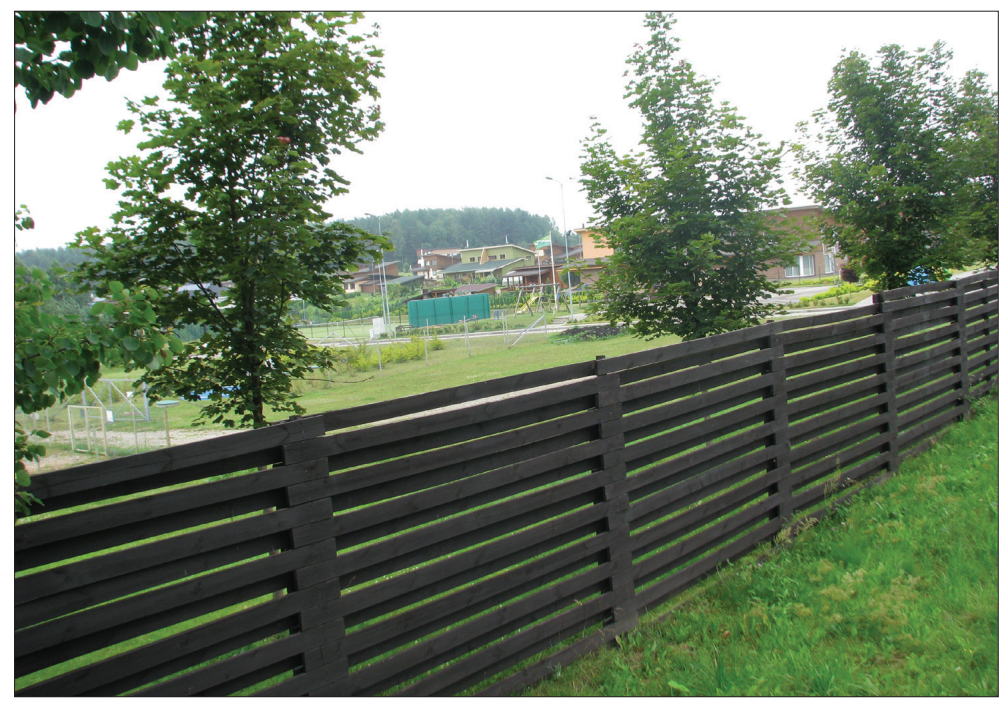

Photo 1. Fences of "Neries kilpos" gated community in Vilnius (Photo: Krupickaite, D.)

living in "Neries kilpos", six with representatives of the municipality, architects and developers of the "Neries kilpos" neighbourhood.

Finally, ten interviews were conducted with developers, real estate agents and administrators of GGNs in other parts of Vilnius. Interviews were carried out in 2010. In addition, in order to get a more comprehensive and reliable picture about the spread of GGNs in Vilnius and its surroundings, content analysis of 16 GGN advertisements and 24 articles about GGN in the country's main newspapers ("Lietuvos rytas", "Respublika", etc.) was performed.

\section{Gated communities in the Vilnius metropolitan region}

The first settlement in Vilnius, which is comparable to present day GGNs was built in Soviet times. In Vilnius and in other capital cities of Soviet republics fenced and strictly secured neighbourhoods were built for the ruling elite. This early development is still in use as the present and past presidents of Lithuania have had their residences there. The first commercial GGN in Vilnius region and in the whole Lithuania was built in 2001 called "Bendorèliai". Later, due to the improvements of economic situation in Lithuania and recovery of real estate market, five more gated communities ( 3 individual blocks and 2 blocks of flats in the city centre) were built by 2006 (Figure 1 and 2). At the same time, the construction of eleven new GGNs (respectively 6 and 5) were started (Pociūtė, G. and Krupickaité, D. 2007). 
Our survey in 2010 showed that thirteen out of fifty-three (around 25\%) newly built neighbourhoods with detached or semi-detached houses in Vilnius region were gated and guarded (Figure 3). Their share on the housing market was

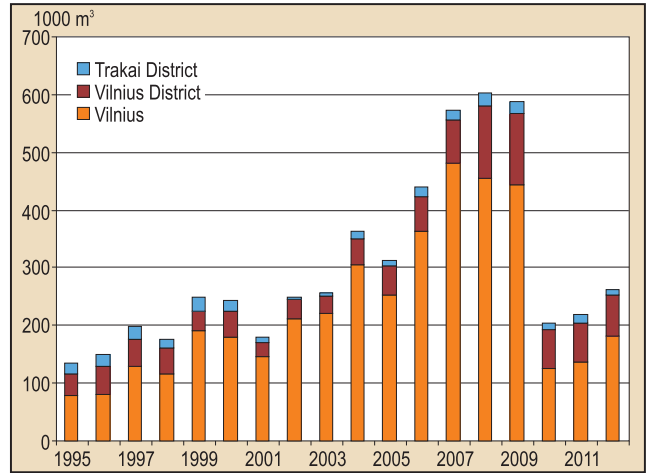

Fig. 1. Residential space completed in Vilnius region in thousand square metres, 1989-2011. Source: Statistics Lithuania Database

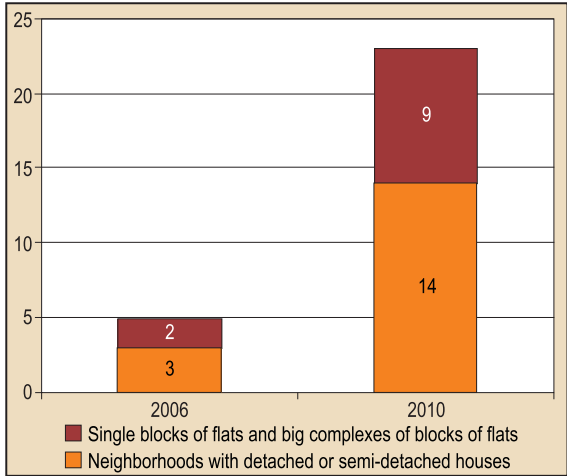

Fig. 2. Number of gated communities in Vilnius region, 2006-2010. Source: own survey

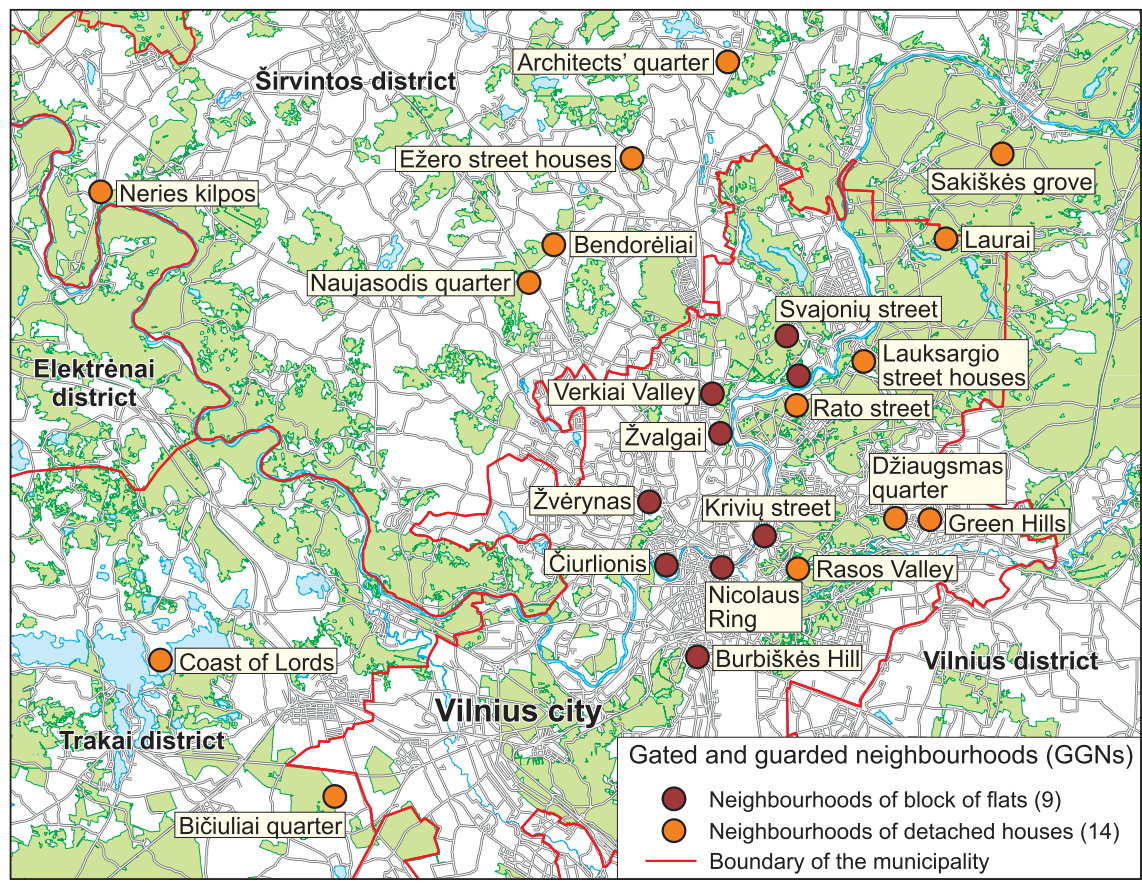

Fig. 3. The location of gated communities in Vilnius region. Source: own survey 
not at all significant they encompassed only around $2.5 \%$ of the housing stock in the Vilnius region, yet, their symbolic role was very important. Also, the economic crisis and other external factors resulted that many GGNs were either not completely built or security control functions were abandoned (only fence remained).

It is important to emphasise that the majority of newly-built neighbourhoods with detached or semi-detached houses (36 out of 40) were fenced and most of them were equipped with automatic gates controlling the entrance to territory (in 24 neighbourhoods). Overall, it can be noticed that the external security measures (i.e. guards, cameras) that are common for classical GGNs, did not play very important role in Lithuania. This can also be related to the fact that an alarm system was installed in most of the newly-built houses. Fencing, however, is dominant feature of GGNs in Lithuania and it plays more important role than other security measures.

The average size of GGN was 24 houses or flats. The number of homes in one GGN varied from 5 to 74. While comparing the level of technical facilities' quality in GGN and other newly-built neighbourhood, it could be observed that the quality was higher in GGN. Such type of neighbourhoods more often had better arranged infrastructure (streets, lighting, sewerage and water supply).

\section{The motivations of actors regarding the development of gated neighbourhoods in Vilnius region}

\section{Motivations of developers to build gated neighbourhoods}

The idea for development of such neighbourhoods in Lithuania came from abroad. The first settlement - "Bendorèliai" - was founded by a Lithuanian who came back from the USA. This company sought to bring the idea of American GGN tradition (Mituziené, A. 2001) (Photo 2). This type of neighbourhood was a novelty in Lithuania, because in the 1990s individual houses were typically built around Vilnius without any infrastructure. These neighbourhoods did not have connection to the city's sewage system and the water was supplied from individual wells. Thus, GGN appeared as a civilised way of building suburban settlements.

However, "Bendorèliai" neighbourhood fulfilled the original idea only partially. People received this novelty with reservations. One of the main reasons of their reservations was an insufficient adjustment of this type of settlement to the Lithuanian housing market. First of all, there was no tradition for building uniform single family houses in the country (it was associated with the uniform constructions of state-socialism). In addition, the plots around the houses were very small in comparison with the regular ones. 


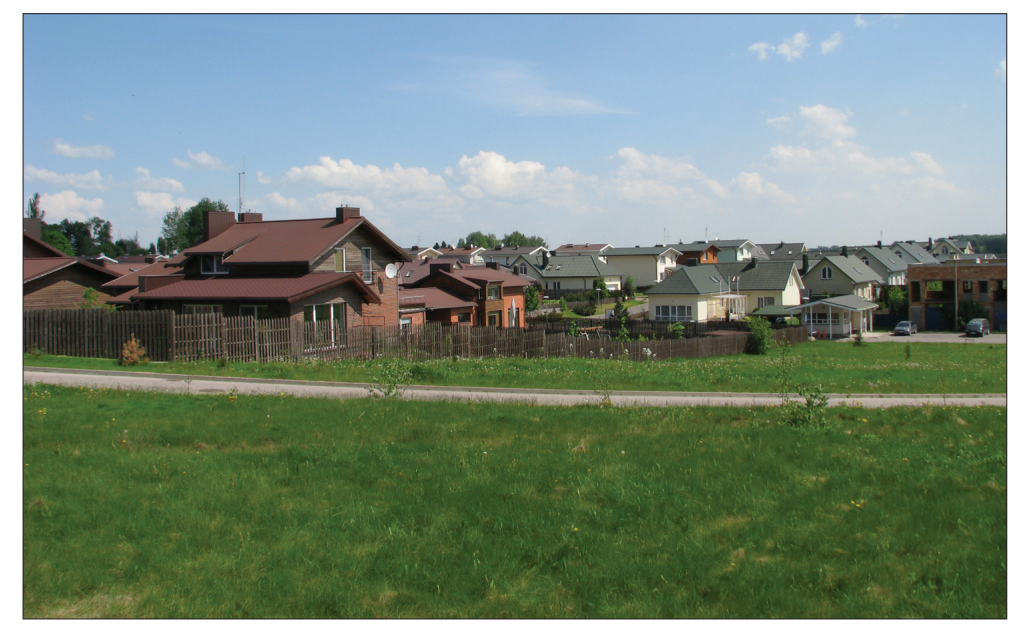

Photo 2. "Bendorèliai" the first gated community in Lithuania (Photo: Krupickaité, D.)

"Neries kilpos" is another good example for the first gated neighbourhoods in Lithuania. Its developer also brought the idea from the US. However, opposed to "Bendorèliai" this project was successful because its layout and development was adjusted to the local market. Part of the success was that by then due to robust economic growth, and improving welfare conditions and credit opportunities demand for gated housing significantly increased on the market. As a result of growing income among better off households exclusive housing projects became more and more attractive.

The detailed analysis of advertisements of gated neighbourhoods revealed that comfort, quality and "fascinating" exclusive landscape were unanimously emphasised by ads. The geographical location in the urban region was another important factor, which was followed by the prestige of the settlement. Regarding the security aspect, the real estate advertisements underlined not only property protection but also the granting of more privacy: „exceptional attention to safety and privacy“ („Verkiu slenis" advertisement), and possibility to leave the children to play in the yard safely: „your children will be able to play safely in the closed courtyards" ("Šaltinių namai" advertisement).

As "Neries kilpos" neighbourhood was developed near the impressive loop of the Neris river (the settlement even has the name of the river), advertisements of this housing compound put special emphasis on environmental aspects. This settlement focused on customers with medium or slightly higher social status, and also on young families due to the relatively long distance from Vilnius city centre and the cheap land. The security aspect was not so much highlighted, even in the initial plan there was no fence. 
According to the experts, the fence became an integral part of such neighbourhoods only later. It allowed to define the borders of the settlement and to distinguish it from the surrounding environment. According to the Director of Lithuanian Real Estate Development Association, one of the main reasons why the majority of newly built neighbourhoods were gated was their artificial nature plain field: "maybe only this fence allows people to feel that it is also a settlement".

According to the developer of "Neries kilpos" residents wanted to fence the settlement because of prestige and exclusiveness. Moreover, it was obvious that the fence and guard of the settlement was not a crucial aspect, but just an extra important advantage which allowed the investors to attract customer's attention easier. The fact that security instalments promised by the investors were not always realised in GGNs also confirms that the question of safety has not always been essential.

At the beginning almost no attention was paid to the emergence of gated communities in the public. On the one hand, the sale of housing in gated neighbourhoods did not differ from other new homes on the market: in most cases the potential buyers were attracted though public advertisements. As it was believed, the place, the price of housing, etc. attracted residents with similar age, status and hobby, and the community would develop unconsciously.

On the other hand, there were some exceptions also among the newly developed GGNs. First of all, houses of the extremely luxurious "Laurai" GGN were sold only to people who had exclusive status and recommendations (PocienĖ, A. 2005; VARnAs, J. 2007). There were also several settlements (i. e. "Džiaugmas" settlement, Photo 3) which were developed by a group of private persons (PocienĖ, A. 2006).

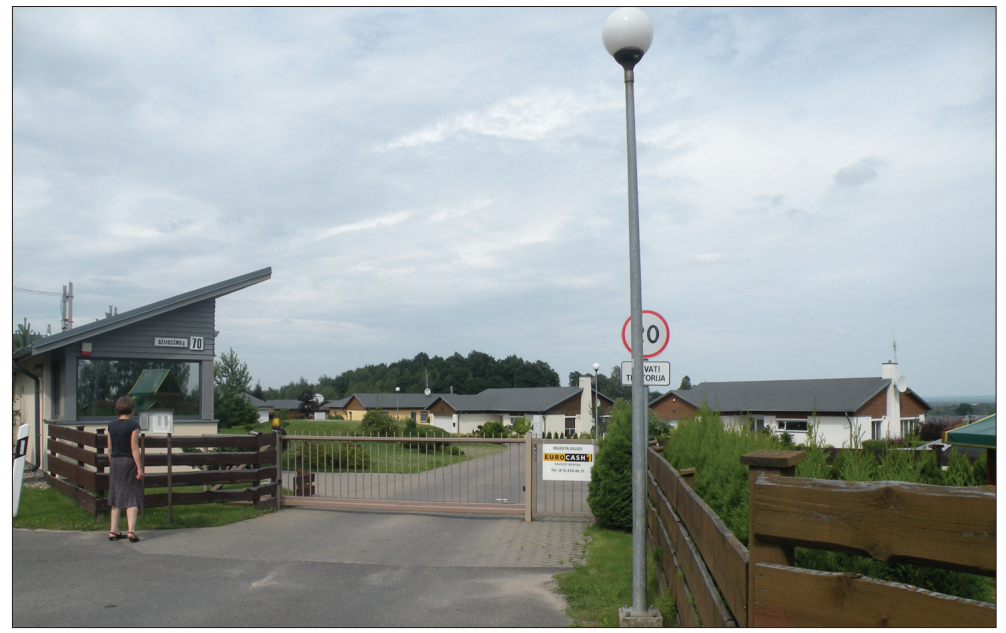

Photo 3. The entrance to "Džiaugmas" gated community (Photo: Peciunonyté, L.) 


\section{Motivations of residents to move into gated neighbourhoods}

An exclusive landscape and attractive place for recreation were the most important motives that inspired the respondents to choose "Neries kilpos settlement": "When we went there, in fact, the view of the landscape amazed us" (male, around 45). Other two criteria which were essential for choosing the "Neries kilpos" settlement were the relatively low price (due of the distance from the city) and the quality of infrastructure.

When choosing the neighbourhood residents also found it important to live together with similar people. Also, they were satisfied with the idea of having common rules and creating jointly a safe neighbourhood (i.e. residents were prohibited to fence their own houses inside the neighbourhood). All these rules made the neighbourhood attractive for people with similar needs and residential ideals.

The community aspect also played an important role in the decision of those who moved in this neighbourhood. Therefore, buying the house in the settlement which had its own rules and an idea of community in advance (to create house owners community) guaranteed a better social security. It was like a creation of safe society model as an opposition to the chaotic environment in the outside world. In such neighbourhood the environment was supervised perpetually and everyone was involved in its supervision. At the same time, residents were independent from the decisions made by clerks: "[Would you like to improve something there?] When we will need, we will improve" (male, 43).

The fact that the neighbourhood would be fenced was not essential: "The fence was not a criterion, not a necessity" (male, around 45). In fact, the fence in "Neries Kilpos settlement" plays two symbolic roles. Firstly, fence is understood as a barrier. It is necessary to close off the neighbourhood from strangers that could bring a feeling of insecurity and uncertainty. The fence clearly defines the safe playground's boundaries for children. In this area residents also take care of each other's children: „Fence is the necessity, because there is a busy road not far away. A lot of cars go there and if we start thinking about children safety..." (male, 33). Secondly, fence is treated as a framework of community spirit: "We want to be different in some way. There should be some border as we do not want to be a hundred separated houses settled somewhere in the fields" (male, around 30). Fence is also understood as a physical boundary between the "wild" nature and the "comfortable" civilised environment.

It might be assumed that isolated settlement is a model of the new lifestyle. It provides an opportunity to live in a "modern" civilised way where everybody complies with the rules. The democratic principles are also applied there: "Also, the management of the place was very interesting. [...] I think 
that if the management of "Neries kilpos" was placed there, people would be able to live much more happily. In our settlement everything is done for the sake of people, not for money" (male, 43). It should be underlined that "Neries kilpos" is not the only gated community where the above mentioned principles played an outstanding role.

According to our interviewee, "Džiaugmas" neighbourhood was established not because of the security needs but because of the wish to have and feel a sense of community. The idea of the community was also essential in "Žali kalnai" settlement. According to experts, the concept of such settlement created conditions for the emergence of community, because residents were forced to take responsibility for the maintenance of their common territory.

\section{Public evaluation of gated and guarded neighbourhoods}

There has been no public opinion on GGNs in Lithuania (except for some discussions on internet web pages). Also, there has been hardly any scientific discussion on this topic (except for a couple of publications). During the last ten years only around 25 press articles appeared in the popular media. The provided information about GGNs was usually neutral or marketing type. Interviewed representatives of Vilnius municipality and planning department were also unable to express an official opinion about gated neighbourhoods. Moreover, admittedly the municipality did not have too much influence over the gating phenomenon: "...if the plot is private, there is an opportunity to fence the territory. The local government cannot do anything about it..." (senior urban planner, Vilnius Municipality).

The fact that the total number of gated communities is quite low in Lithuania explains why so little attention has been paid to them. As it was mentioned, these settlements have been developed only recently and they are associated with the comprehensively developed settlements. As long as GGNs maintain their own infrastructure (road, green areas etc) they are perceived positively by city administrators: "Such situation is economically profitable for us. There is no difference, if it is fenced or not". Another local government official emphasised: "...behind the fence there is more cleanness, because with fencing you become responsible for your territory". Fencing was seen only as one of the elements of the infrastructure, it was considered similar to fencing a family house: ,....everyone thinks about his own quality of life and can fence his territory. The same is with the community. If its members decide to build a fence, it is their choice...". The foundation of GGNs was not the desire of planners; it was more determined by the demand on the market and planners did not have any power to influence it. 


\section{Discussion and conclusions}

It is possible to distinguish several aspects that describe the main features of the Lithuanian model of gating phenomenon:

- Gated and guarded neighbourhoods in Lithuania have been established quite recently. Such neighbourhoods form one type of new housing developments, i.e. a variant of a complex neighbourhood with full infrastructure. They comprise a relatively small part of the housing market and the phenomenon is neither typical nor widespread. The morphology of gated neighbourhoods slightly differs from other types of neighbourhoods; however, they are better equipped.

- The first gated settlements were built according to the ideas brought from the USA. However, GGNs became successful only after their adoption to the needs of the Lithuanian market. Thus, the development of GGNs in Lithuania is distinctive and corresponds to the local peculiarities.

- The most important aspects for the residents living in such neighbourhoods are the community, assurance of safe social environment, economic profit, the lack of control compensation and maintenance of the settlement.

- Fence in GGNs is a symbol of the border which determines safe and united space. It also provides physical security for children. As a result, the investors tend to create an image of GGN as a safe, and more comfortable residential area. As the maintenance of security is quite expensive, only a small part of GGN residents want to invest in them.

- As the construction of such neighbourhoods is related to the development of advanced individual housing model, the public opinion about them is positive.

The above mentioned aspects might be found in other countries. However, some differences between Lithuanian and foreign gated communities can also be pointed out. First of all, the development of GGNs in Lithuania was started later than in other post-socialist countries, and they did not receive such popularity as in Russia, Poland, Hungary, and the Czech Republic. Also, there are almost no manifestations of luxury. These settlements are not exclusively prestigious.

It is possible to hypothesise that an important factor for the limited development and variety of such neighbourhoods is the size of the housing market. The housing market in Lithuania is relatively small and it does not attract big foreign investors - almost all such neighbourhoods were built by small local companies. Of course, it is difficult to check this hypothesis without thorough analysis of GGNs in Estonia and Latvia; however, the development of GGNs in Lithuania differs from the tendencies in other post-socialist countries, and it is more similar to the trends of countries where such type of living is not very popular (e.g. Spain, France). 
Yet, the idea to live in a small closed community with people of similar status and to enjoy the beauty of the environment becomes more and more attractive as well. As our case-studies showed residents of such neighbourhoods wanted to realise some of these ideas. Moreover, children also play an important role; their safety regularly comes to the fore. To sum up, as people miss social safety in the chaotic outside world where they face a lot of unsolved problems, such neighbourhoods provide an alternative with their safe and ordered landscape.

The residents' wish to isolate themselves from the outside world, the desire to fence the territory around their houses can be paradoxically associated with the formation of civil society. In other words, residents want to take the responsibility for the territory which is near their houses, but at the same time they want to know that they can maintain the order. Therefore, they seek to get the possibility for fencing their territory. This would also allow them to create a more predictive and socially safer environment.

Acknowledgements: This research was supported by DFG (Deutsche Forschungsgemeinschaft), through the research project "Between gentrification and downward spiral: Socio-spatial change and persistence in residential neighbourhoods of selected East-Central European urban regions", organised by the Leibniz Institute for Regional Geography. The Research Council of Lithuania also contributed to our survey while implementing "Promotion of Students' Scientific Activities" programme and providing fund for our student Laura Peciukonyté in 2010. The authors are also grateful to dr. Gediminas Tomas Murauskas for his help.

\section{REFERENCES}

Bitusikova. A. and Luther, D. 2010. Sustainable diversity and public space in the city of Bratislava, Slovakia. Anthropological notebooks 16. (2): 5-18.

Blandy, S. 2006. Gated Communities in England: historical perspectives and current developments. GeoJournal 66. 15-26.

Blandy, S. and Parsons, D. 2003. Gated Communities in England: rules and rhetoric of urban planning. Geographica Helvetica 58, 314-324.

Blankley, E.J. and Snyder, M.G. 1997. Fortress America: Gated Communities in the United States. Brookings Institution Press and Lincoln Institute of Land Policy, Washington, DC and Cambridge, MA.

Blinnikov, M., Shanin, A., Sobolev, N. and Volkova, L. 2006. Gated communities in Moscow green belt: newly segregated landscapes and the suburban Russian environment. GeoJournal 66, 65-81.

Brade, I., Herfert, G. and Wiest, K. 2009. Recent trends and future prospects of socio-spatial differentiation in Urban regions of Central and Eastern Europe: A lull before the storm? Cities 26. 233-244.

Brady, R. 1999. Kapitalizm: Russia's struggle to free its economy. Yale University Press, New Haven. 
Cséfalvay, Z. 2009. Demythologising gated communities in Budapest. In Gated and Guarded Housing in Eastern Europe. Ed. Schmigiel, C. Forum IFL 11. Leibniz Institut für Länderkunde, Leipzig. 35-47.

Cséfalvay, Z. and Webster, C. 2012. Gates or No Gates? A Cross-European Enquiry into the Driving Forces behind Gated Communities. Regional Studies 46. (3): 293-308.

Csizmady, A. and Csanádi, G. 2009. From Housing Estates to Gated Communities. In Gated and Guarded Housing in Eastern Europe. Ed. Schmigiel, C. Forum IFL 11. Leibniz Institut für Länderkunde, Leipzig. 9-19.

Frantz, K. 2001. Gated Communities in Metro-Phoenix (Arizona). Geographische Rundschau 53. (1): 12-18.

FranTz, K. 2006. Private gated neighbourhoods: a progressive trend in US urban development. In Private Cities: Global and local perspectives. Eds. Glasze, G. et al. Routledge, London, New York, 61-72.

Glassner, B. 1999. The Culture of Fear. Why Americans are Afraid of the Wrong Things. Basic, New York.

Glasze, G. 2003. Bewachte Wohnkomplexe und "die europäische Stadt" - eine Einführung. Geographica Helvetica 58 (4): 325-339.

Glasze, G. 2005. Some Reflections on the Economic and Political Organization of Private neighbourhoods. Housing Studies 20. (2): 221-233.

Gmünder, M., G. Grillion, N. and Bucher, K. 2000. Gated Communities. Ein Vergleich privatisierter Wohnsiedlungen in Südkalifornien. Geographica Helvetica 55. (3): 193-203.

Handley, J. 2002. After Terrorist Attacks, Different Opinions Form about Gated Communities, Chicago Tribune (IL) 8. 12-19.

Hegedús, G. 2009a. Features of Gated Communities in the Most Populous Hungarian Cities. In Gated and Guarded Housing in Eastern Europe. Ed. Schmigiel, C. Forum IFL 11. Leibniz Institut für Länderkunde, Leipzig. 91-99.

Hegedús, G. 2009b. A Review of Gated Communities in Some Hungarian Cities. Geographica Pannonica 13. (3): 85-96.

Johnson, C. 2009. The status of gates in Belgrade: notes on style and markets. In Gated and Guarded Housing in Eastern Europe. Ed. Schmigiel, C. Forum IFL 11. Leibniz Institut für Länderkunde, Leipzig. 21-28.

Kovács, Z. and Hegedús, G. 2014. Gated communities as new forms of segregation in postsocialist Budapest, Cities 36. 200-2009.

Krupickaitė, D. and Pociūtė, G. 2009. Gated and Guarded Housing in Lithuania. In Gated and Guarded Housing in Eastern Europe. Ed. Schmigiel, C. Forum IFL 11. Leibniz Institut für Länderkunde, Leipzig. 75-81.

LeE, S. and Webster, C. 2006. Enclosure of the urban commons. GeoJournal 66. 27-42.

Lentz, S. 2006. More gates, less community? Guarded housing in Russia. In Private cities: global and local perspectives. Eds. Glasze, G. et al. Routledge, London, 206-221.

Lentz, S. and Lindner, P. 2003. Privatisierung des öffentlichen Raumes - soziale Segregation und geschlossene Wohnviertel Moskaus. Geographische Rundschau 55. (12): 50-57.

Low, S. 2004. Behind the gates: life, security, and the pursuit of happiness in fortress America. Routledge, New York, London.

Madoré, F. and Glasze, G. 2003. L'essor des ensembles résidentiels clos en France: un phénomenè en expansion et aux ressorts multiples. Geographica Helvetica 58. (4): 325-339.

Marcuse, P. 1997. Walls of fear and walls of support. In Architecture of Fear. Ed. Ellin, N. Princeton Press, Princeton. 
McKenzie, E. 1998. Homeowner Associations and California Politics: An Exploratory Analysis. Urban Affairs Review 34. (1): 52-74.

Mituziene, A. 2001. Naujo būsto mados. Veidas, 200103 22, 26-30.

Negura, O. 2009. Residential ensembles in „hypermodern times“. A case study of their aspirations in Bucharest. In Gated and Guarded Housing in Eastern Europe. Ed. Schmigiel, C. Forum IFL 11. Leibniz Institut für Länderkunde, Leipzig. 59-67.

Pociené, A. 2005. Turtingi lietuviai jau gali pasirinkti ir savo kaimynus. Lietuvos rytas / Būstas 31. 5.

Pociené, A. 2006. Architektai raško saldžius drąsios idèjos vaisius. Lietuvos rytas / Būstas 6. $1-2$.

Pocıūtė, G. 2007. Teritoriškai uždaru bendruomeniu Vilniuje ir jo apylinkèse vystymosi ypatumai, Bakalauro darbas. Vilniaus universitetas, Vilnius.

Pociūté, G. and KRupickaitė, D. 2007. Gated Communities in Lithuania: tendencies and peculiarities (a Case of Vilnius and its Environs). Annales Geographicae 40. (2): 14-27.

PolansKa, D.V. 2010a. Gated Communities and the Construction of Social Class Markers in Postsocialist Societies: The Case of Poland. Space and Culture 13. (4): 421-435.

PolansKa, D.V. 2010b. The emergence of gated communities in post-communist urban context: and the reasons for their increasing popularity. Journal of Housing and the Built Environment 25. 295-312.

Raposo, R. 2003. New landscapes: Gated housing estates in the Lisbon Metropolitan Area. Geographica Helvetica 4. 293-301.

Raposo, R. 2006. Gated communities, commodification and aestheticization: The case of the Lisbon metropolitan area. GeoJournal 66. 43-56.

Rudolph, R. and Lentz, S. 1999. Segregationstendenzen in russischen Großstädten: Die Entwicklung elitärer Wohnformen in St. Petersburg und Moskau. Europa Regional 7. $27-40$.

Schmigiel, C. 2009. Preface and Introduction. In Gated and Guarded Housing in Eastern Europe. Ed. Schmigiel, C. Forum IFL 11. Leibniz Institut für Länderkunde, Leipzig 5-8.

Stanilov, K. 2007. Democracy, markets, and public space in the transitional societies of Central and Eastern Europe, available at: http://tiranaworkshop09.pbworks.com/f/kiril+stani lov+democracy+markets+and+public+space+in+the+transitional+societies+of+CCE. pdf [4 February 2013]

Stoyanov, P. and Frantz, K. 2006. Gated communities in Bulgaria: interpreting a new trend in post-communist urban development. GeoJournal 66. 67-63.

VArnas, J. 2007. Paslaptingiausias gyvenamasis kvartalas Vilniuje. Vilniaus diena. http://www. delfi.lt/news/economy/realestate/paslaptingiausias-gyvenamasis-kvartalas-vilniuje. d?id=15038300 (2007 11 17)

Voslensky, M.S. 1984. Nomenklatura: The Soviet ruling class. Garden City. Doubleday, New York.

Wehrhahn, R. 2003. Gated communities in Madrid: Zur Funktion von Mauern im europäischen Kontext. Geographica Helvetica 58. (4): 302-313.

Wehrhahn, R. and Raposo, R. 2006. The rise of gated residential neighbourhoods in Portugal and Spain. In Private Cities: Global and local perspectives. Eds. Glasze, G. et al. Routledge, London, New York. 